anales de psicología, 2017, vol. 33, $\mathrm{n}^{\circ} 2$ (may), 376-382 http://dx.doi.org/10.6018/analesps.33.2.256971
(C) Copyright 2017: Servicio de Publicaciones de la Universidad de Murcia. Murcia (Spain) ISSN print edition: 0212-9728. ISSN web edition (http://revistas.um.es/analesps): 1695-2294

\title{
What are the most representative warning signs of intimate partner violence against adolescent girls?
}

Ainara Nardi-Rodríguez ${ }^{1 *}$, María-Ángeles Pastor-Mira ${ }^{1}$, Sofía López-Roig1 and Victoria-Aurora Ferrer-Pérez ${ }^{2}$

${ }^{1}$ Health Psychology Department, Miguel Hernández University, Elche (Spain)

${ }^{2}$ Psychology Department, Islas Baleares University, Palma de Mallorca (Spain)

Título: ¿Cuáles son las señales de alarma más representativas de la violencia de pareja contra las adolescentes?

Resumen: Identificar qué señales de alarma de violencia de género (VG) en la adolescencia deben incluirse en los programas de prevención es esencial. Al no existir un acuerdo explícito al respecto, nuestro primer objetivo fue identificar qué señales son más frecuentes en las guías de prevención españolas revisadas, mediante un análisis de contenido realizado independientemente por 3 juezas. Nuestro segundo objetivo fue valorar una muestra de adolescentes $(n=60)$ para conocer: (1) si las identifican como conductas violentas; (2) con qué frecuencia consideran que deben ocurrir para ser señales de alarma, y (3) con qué frecuencia las observan en su entorno de iguales. Entre las 23 señales identificadas, las conductas de control (n = 11) y desvalorización $(n=6)$ son las más frecuentes en la literatura revisada y prevalentes en los grupos de iguales $(52.5 \%$ - 90\%). La mayoría identificó las 23 conductas como violentas. Cuatro conductas de control y 3 de desvalorización tienen que darse a menudo para ser consideradas señales de alarma de VG. Por tanto, su tolerancia a las mismas es elevada. Estos resultados son útiles para la elaboración de programas de prevención y sugieren la necesidad de investigar sobre los factores explicativos de dicha tolerancia.

Palabras clave: Adolescencia; violencia de género; programas de preven-

ción; señales de alarma; conductas violentas de baja intensidad

\section{Introduction}

In Spain, social and political concern about intimate partner violence (IPV) against adolescent girls is increasing at a staggering speed, especially regarding psychological abusive behaviours, which has been clearly understudied despite its relevance to the understanding of IPV (Kelly, 2004; RodríguezCarballeira, Porrúa-García, Escartín, Martín-Peña, \& Almendros, 2014). Young people tolerate (32\% girls and $34 \%$ boys) (CIS, 2013) and experience certain forms of abuse such as controlling behaviours in higher rates than adults (Government's Delegation for Gender Violence, 2015). Experts emphasize on the need to set the spotlight on psychological abuse for its prevalence (Liles et al., 2012), greatest impact on health (Bell, Bennett, Goodman, \& Dutton, 2008; Kelly, 2004) and link with later physical abuse (Henning \& Klesges, 2003).

Marshall (1999) differenciated between overt and subtle forms of psychological abuse, both a source of emotional harm. Subtle forms can be difficult to detect since they can be disguised under tokens of love, games or jokes (Luzón, Ramos, Recio \& Peña, 2011; Marshall, 1999). This can lead to girls'misinterpretation and therefore to their continuity in abusive relationship. Taking into account that violence generally settles in gradually and eventually evolves into higher intensity over time (González- Ortega, Echeburúa, \& de

* Correspondence address [Dirección para correspondencia]

Ainara Nardi-Rodríguez. Universidad Miguel Hernández. Edificio Altamira Universidad Miguel Hernández de Elche. Departamento de Psicología de la Salud. Avda/ de la Universidad s/n, 03202, Elche, Alicante (Spain). E-mail: anardi@umh.es
Abstract: Identifying which warning signs (WS) of intimate partner violence against girls (IPV) must be included in prevention programs is essential, since there is not an explicit consensus. Our first aim was identifying the most frequent WS included in the reviewed Spanish prevention guides by means of a content analysis performed independently by three judges. Our second aim was subjecting these to a sample of adolescents $(n=60)$ to know: (1) if they identify them as abusive behaviours; (2) how frequently do they consider they have to occur to be WS, and; (3) how frequently they observe them in their peer environment. Among the 23 identified WS, controlling $(n=11)$ and devaluating behaviours $(n=6)$ are the most frequent in the reviewed literature and the formers the most observed in the adolescents' environment (rank: $52.5 \%$ - 90\%). The majority labelled the 23 behaviours as abusive. Four controlling and 3 devaluating behaviours had to occur very often to be an IPV warning sign. Therefore their tolerance to these WS is high. The outcomes are valuable for the development of prevention programs and suggest the need of investigating on the explanatory factors of such tolerance.

Key word: Adolescence; intimate partner violence; prevention programs; warning signs; low intensity violent behaviours.

Corral, 2008; Luzón, et al., 2011; Povedano, 2014), it's a priority for primary prevention purposes to identify what we labeled as low intensity violent behaviours (LIVB), this is, psychologically abusive behaviours pursuing girls' subjection that can adopt subtle forms in the adolescent stage and that are thus likely to appear in the first stages of a relationship. Regardless the relevance of LIVBs, these have not been explicitly defined and agreed.

In Spain, UK and USA prevention guides and field studies (see references: single asterisk for Spanish guides and studies, and double asterisk for UK and USA guides) focus on a large range of warning signs (WS) including physical and sexual violent behaviours. Hence, not all WS are likely to be LIVB. In order to spot LIVBs by means of a Delphi study (Nardi-Rodríguez, Pastor, López-Roig, \& Ferrer-Pérez, 2016), our first aim was identifying the most representative psychological WS of IPV against girls employed in Spanish prevention guides. Our second aim was to draw an overview of how these are perceived by adolescents, this is: (1) to know if they identify WS as abusive behaviours; (2) how frequently behaviours have to take place for considering them WS, and (3) how prevalent are they in their peer environment.

\section{Method}

\section{Participants}

For the first aim of this study, two judges were in charge of classifying and assembling the WS independently. Dis- 
crepancies were resolved by a third judge. All three judges are authors of this article.

For the remaining goals, 60 heterosexual adolescents from 14 to 18 years old participated in a survey study. Most of them were female $(68.3 \%), 35 \%$ over 16 . Among boys $(31.7 \%), 15 \%$ were under 16 and $16 \%$ over 16 . The mean age was 16.08 (CI [15.72-16.28]; $M d n=16 ; S D=0.85)$.

\section{Procedure}

Warning signs were culled from studies or prevention guides focused on Spanish adolescent population and commissioned by a governmental institution or Non- Government Organisation renowned for its work in preventing IPV against girls. Eight sources were finally selected (marked with one asterisk in the reference section). WS were compiled in a document and classified according to the strategy to which they referred to: controlling, devaluating, emotional blackmail, sexual blackmail, threat \& intimidation, and sexist behaviours. For the content analysis, we followed the methodology used in the reasoned action approach (Fishbein \& Ajzen, 2010) for the selection of salient beliefs. Two judges performed independently the analysis, putting similar behaviours into groups. New items were formulated representing each group of similar WS. Thus, this reduced list of items embodied the most representative WS. At the end of each stage, judges would compare their classifications and resolve discrepancies by means of a third judge and consensus.

The most representative psychological WS were subjected to a sample of adolescents. The questionnaire was previously tested with a focal group composed of 8 adolescents (4 males and 4 females) between 14 and 18 years old, to assure the comprehension and face validity. Then we contacted with the director of a Youth Centre in Alicante, an alternative to free time for adolescents of all areas of Alicante. The process and aims of the study were explained in detail, emphasizing on its compliance with the ethical criteria established by the Miguel Hernández University Ethics Committee and by the Helsinki's statements. The researchers presented the study to the sample composed of 78 sociodemographically heterogeneous adolescents and handed out selfadministered anonymous questionnaires. Consent report had to be filled in beforehand. Eighteen questionnaires were discarded since they were not filled in accurately. Adolescents had to: (1) classify the WS listed as non-violent behaviours, LIVB, or high intensity violent behaviours (HIVB); (2) indicate the frequency with which behaviours classified as LIVBs had to take place to be considered IPV warning signs (once, sometimes or very often) and (3) indicate how often do they observe the WS among their peers (never, sometimes or very often).

For both aims we developed a definition of LIVB rooted in Luis Bonino's definition of Every Day Male Chauvinism (1993) and Luzón et al. (2011) description of subtle behaviors: 'We conceive LIVB as those behaviours performed by adolescent males that attempt against girls' autonomy, and psychological and social well-being, that can be subtle or difficult to detect by them and that take place to maintain or gain a dominant position on girls.

We employed the chi square tests to analyse differences between male and female answers, and the Bonferroni's correction was applied for significance $(\mathrm{p} \leq .002)$.

\section{Results}

\section{Judges' analysis of the warning signs comprehended in Spanish prevention guides and field studies}

The complete process and results are detailed online (see https://drive.google.com/folderview?id=0BzSPxW3ojgDz ODJLcFZhRTJsS2M\&usp=sharing).

\section{List of behaviours culled from the different sources}

A total of 123 behaviours were poured out from the 8 sources.

\section{Elimination of behaviours which are clearly not LIVB}

Behaviours designed to break acquiescence effect were eliminated as well as those referred to explicit violence (physical and sexual violence). Twenty one behaviours were eliminated, remaining a total of 102.

\section{Classification of warning signs according to aggressor's strategy}

Strategy classification proposed in the study promoted by Andalucía's Women National Institute (Luzón et al., 2011) was chosen for its appropriateness to adolescent Spanish context. This classification is similar to the Teen Power and Control Wheel (Pence, \& Paymar, 1993) (Table 1). Either classification is useful. The reason why we tip the scale in favour of the Spanish classification is because the sources from which the warning signs came from were Spanish. Behaviours could refer to eight strategies: 1) Control, ownership, possession and jealousy (from now on control strategy); 2) Isolating the victim from their social environment (isolation strategy); 3) devaluating the victim ; 4) threatening and intimidating the victim; 5) emotional blackmailing; 6) coercion or sexual abuse (sexual blackmail strategy); 7) physical violence; and 8) sexist behaviours. For the reasons discussed above, physical violence dimension was not considered. In addition, behaviours referring to sexual abuse were eliminated, leaving only those referring to sexual blackmail. This first analysis allowed us to organize behaviours and ensure the representativeness of the different strategies of interest and whether these were present in all sources. Control strategy (which includes isolating behaviours as these refer to a higher degree of control and therefore were grouped further on under the same strategy) and devaluation strategy are considered in all 8 sources (Table 2). Likewise, control- 
ling and devaluating behaviours are the most numerous ones in all sources. Controlling behaviours outnumbered devaluating ones in 6 sources. Emotional blackmail and sexist behaviours are both the less represented strategies in the reviewed literature (present in 3 and 2 sources respectively).
The number of behaviours that remained at the end of this stage was 117, a higher number than in the previous step as behaviours that were compounded by other two were divided in order to calculate the frequency with which behaviours appear in the different sources.

Table 1. Strategies' representation and percentage of behaviours per strategy in the different sources.

\begin{tabular}{|c|c|c|c|c|c|c|c|}
\hline \multirow[t]{2}{*}{ Source } & \multicolumn{7}{|c|}{ Strategy $^{\mathrm{a}}$} \\
\hline & Control & Devaluation & $\begin{array}{c}\text { Threat \& } \\
\text { intimidation }\end{array}$ & $\begin{array}{l}\text { Emotional } \\
\text { blackmail }\end{array}$ & $\begin{array}{c}\text { Sexual } \\
\text { blackmail }\end{array}$ & $\begin{array}{c}\text { Sexist } \\
\text { behaviour }\end{array}$ & Total $^{\mathrm{b}}$ \\
\hline Nuez del Rosario, 2005. & 43.5 & 30.5 & 26 & - & - & - & 3 \\
\hline Instituto Andaluz de la Mujer, 2009. & 54.5 & 9.1 & 9.1 & 9.1 & 18 & - & 5 \\
\hline Luzón et al., 2010 & 38.7 & 16.1 & 6.4 & 9.7 & 9.7 & 19.3 & 6 \\
\hline Rodríguez, 2010 & 60 & 20 & - & 20 & - & - & 3 \\
\hline Díaz-Aguado, et al., 2011 & 18.1 & 36.3 & 36.3 & - & 9 & - & 4 \\
\hline Centro de Estudios de la Mujer, 2011. & 44.4 & 33.3 & - & - & 11 & 11 & 4 \\
\hline Gálligo, 2010 & 40 & 46.6 & 6.6 & - & 6.6 & - & 4 \\
\hline Díaz-Aguado, et al., 2014 & 35.7 & 28.5 & 28.5 & - & 7.1 & - & 4 \\
\hline Totalc & 8 & 8 & 8 & 3 & 6 & 2 & \\
\hline
\end{tabular}

a Data refers to the percentage of behaviours belonging to each strategy included in a source. This calculation is based on the behaviours once divided and classified in the different strategies in our study. ${ }^{\mathrm{b}}$ Total of strategies represented in each source. ${ }^{\mathrm{c}}$ Total of sources that include each strategy.

Table 2. Classification of warning signs by adolescents.

\begin{tabular}{|c|c|c|c|c|c|}
\hline \multirow[b]{2}{*}{ Strategy and Behaviours } & \multicolumn{3}{|c|}{ Non-violent } & \multicolumn{2}{|l|}{ LIVB } \\
\hline & $\mathrm{T}^{\mathrm{a}}$ & Girls & Boys & Ta GirlsBoys & Ta GirlsBoys \\
\hline \multicolumn{6}{|l|}{ CONTROL } \\
\hline 1-He criticizes the way I dress or make up & 15 & 14.6 & 10.5 & \begin{tabular}{lll|}
76.7 & 78 & 73.7
\end{tabular} & $8.3 \quad 4.9 \quad 15.8$ \\
\hline 2- He asks me to change the way I dress or make up & 16.9 & 10 & 31.6 & 52.557 .542 .1 & 30.532 .526 .3 \\
\hline 3- He checks and controls my mobile or emails or social networks & 6.8 & 2.5 & 15.8 & 33.925 .747 .4 & $59.370 \quad 36.8$ \\
\hline 4- He uses my passwords to supplant my identity or control me & 1.7 & 0 & 5.3 & $\begin{array}{lll}15 & 9.8 & 26.3\end{array}$ & 83.390 .268 .4 \\
\hline 5- He tells me that he needs to know where I'm going, with who and what I'm doing & 11.7 & 14.6 & 5.3 & $\begin{array}{lll}38.3 & 39 & 36.8\end{array}$ & 5046.357 .9 \\
\hline $\begin{array}{l}\text { 6- He phones me several times to know where am I, with whom, what am I doing and } \\
\text { when are we going to see each other }\end{array}$ & 10 & 14.6 & 0 & 53.331 .747 .4 & 36.753 .752 .6 \\
\hline 7- He frequently gets jealous & 35.6 & 35 & 36.8 & $45.8 \quad 50 \quad 36.8$ & $18.615 \quad 26.3$ \\
\hline 8- He accuses me with certain frequency of having an affair with another person & 6.7 & 2.4 & 15.8 & 43.351 .226 .3 & 5046.357 .9 \\
\hline 9- He often asks me not to go out with my friends & 1.7 & 2.5 & 0 & $\begin{array}{lll}18.6 & 7.5 & 42.1\end{array}$ & $\begin{array}{lll}79.7 & 90 & 57.9\end{array}$ \\
\hline 10- He speaks badly of my family or friends & 8.3 & 4.9 & 15.8 & 36.734 .142 .1 & $\begin{array}{lll}55 & 34.1 & 42.1\end{array}$ \\
\hline 11- He tries to isolate me from & 3.4 & 2.6 & 5.3 & $\begin{array}{lll}12.1 & 5.1 & 26.3 \\
\end{array}$ & 84.592 .368 .4 \\
\hline \multicolumn{6}{|l|}{ DEVALUATION } \\
\hline 12- He ignores me, he & 15 & 17.1 & 10.5 & 43.351 .226 .3 & 41.731 .763 .2 \\
\hline 13- He ignores me or punishes me with silence & 13 & 12.2 & 15.8 & 36.734 .142 .1 & $\begin{array}{lll}50 & 53.7 & 42.1\end{array}$ \\
\hline 14- He compares me with other girls and makes me feel uncomfortable and humiliated & 0 & 0 & 0 & 28.324 .436 .8 & 71.775 .663 .2 \\
\hline 15- He insults me or ridicules me publicly or privately & 1.7 & 0 & 5.3 & $11.7 \quad 7.321 .1$ & 86.792 .773 .7 \\
\hline $\begin{array}{l}\text { 16- He frequently criticizes me publicly or privately for the way I think, speak or for oth- } \\
\text { er reasons }\end{array}$ & 3.4 & 0 & 11.1 & $20.7 \quad 10 \quad 44.4$ & $75.990 \quad 44.4$ \\
\hline 17- He tells me to shut up and not talk nonsense or makes fun of my opinions & 1.7 & 0 & 5.3 & 28.326 .831 .6 & 7073.263 .2 \\
\hline \multicolumn{6}{|l|}{ THREAT \& INTIMIDATION } \\
\hline 18- He shouts and speaks badly at me & 1.7 & 0 & 5.3 & 18.314 .626 .3 & $80 \quad 85.468 .4$ \\
\hline 19- He threatens me, intimidates me or makes me feel afraid & 1.7 & 0 & 5.3 & 1.7 & 96.710089 .5 \\
\hline
\end{tabular}
EMOTIONAL BLACKMAIL

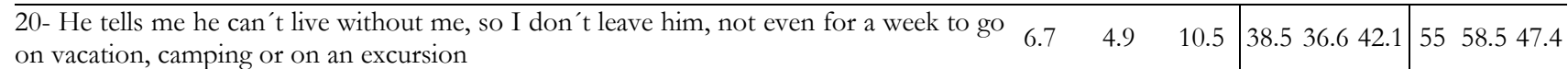
SEXUAL BLACKMAIL

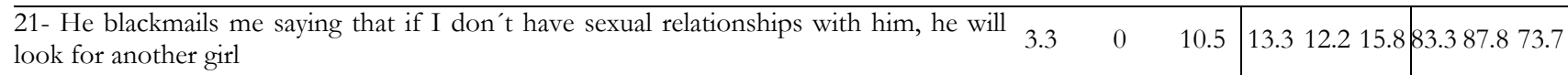

22- He pressures me to have sexual relationships when I don't want to

\begin{tabular}{lll|l|l|l|l}
3.3 & 0 & 10.5 & 18.3 & 14.6 & 26.3 & 78.385 .463 .2 \\
\hline
\end{tabular}

SEXIST BEHAVIOUR

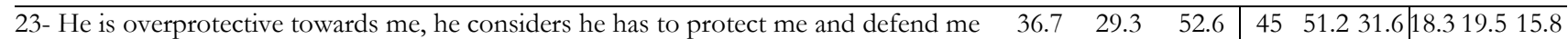

Note: In table only valid percentage of behaviours' classification. ${ }^{\text {a }}$ Total percentage of female and male adolescents who classified the behaviours, as nonviolent behaviour, low intensity violent behaviour (LIVB), or high intensity violent behaviour (HIVB). 


\section{Grouping behaviours according to content similarity}

Our purpose was to group similar content behaviours together. Therefore within each strategy, new groups composed of similar behaviours were formed. At the end of this step, 90 behaviours were classified in 18 groups and 22 behaviours remained non-grouped.

\section{Frequency analysis of behaviours with similar content}

After performing a frequency analysis of similar content behaviours, the 22 non-grouped behaviours were eliminated since they were only mentioned in a unique source (frequency $=1$ ). Two groups composed of 2 and 5 similar behaviours were also eliminated since they proceeded from the same source (frequency $=1$ ). In all, 90 behaviours remained classified in 16 groups.

Grouping behaviours according to content severity similarity and items formulation

Within every group composed of similar content behaviours, these were regrouped according to their severity or intensity. New items were formulated for each new group of behaviours in order to represent their similar content and intensity. Behaviours that were composed of other two behaviours with similar content but expressing different severity degree were divided. At the end of this stage, 24 items represented 76 behaviours and 15 remained non-grouped.

\section{Frequency analysis of behaviours with similar content severity}

After performing a frequency analysis of similar content severity behaviours, non-grouped behaviours were eliminated $(n=15)$ (frequency $=1)$. One cluster composed of 2 similar behaviours proceeding from the same source was eliminated too. Therefore 23 items remained representing 74 behaviours.

\section{List with the most representative warning signs}

Twenty three items represented the most frequent psychological WS signs (Table 3). Almost half of them belonged to the control strategy $(n=11)$, and a quarter to devaluation strategy $(n=6)$.

\section{Subjecting behaviours to a sample of adolescents}

Of the $23 \mathrm{WS}, 17$ were classified as HIVB. The other 6 behaviours were labelled as LIVB: the agreement ranged from $43.3 \%$ (item 12) to $76.7 \%$ (item 1), although 4 of them rounded $43-53 \%$. None were considered non-violent by a majority of adolescents. According to strategies, all the behaviours referring to threat $\&$ intimidation, sexual blackmail and emotional blackmail were labelled as HIVB. Within the 6 behaviours considered LIVB, 4 belonged to the control strategy (item 1, 2, 6, and 7), 1 to the devaluation strategy (item 12) and 1 to the sexist behaviour strategy (item 23) (Table 2).

Regarding the behaviours that were classified by each one of the participants as LIVB that have to occur very often to be considered a WS, the sexist behaviour obtained the highest percentage of agreement (74\%) (Table 3). More than half of the sample believed the same concerning 4 controlling behaviours, ranging the percentage of agreement from a low $56.3 \%$ (item 6 ) to a high of $66.6 \%$ (item 7). Three devaluating behaviours were judged by at least $52.9 \%$ of the sample to have to happen very often (i.e. item 14). Unanimously, nobody considered that 2 controlling behaviours (item 4 and 11) and 1 threat $\&$ intimidation behaviour (item 19) had to occur very often to be WS. Comparison between male and female population was not possible since a very small percentage of adolescents classified the behaviours as LIVB.

Table 3. Observation of warning signs amongst peers and percentage with which adolescents believe that LIVBs must appear very often to be an IPV warning sign

\begin{tabular}{|c|c|c|c|c|c|c|c|}
\hline \multirow[b]{2}{*}{ Behaviour } & \multicolumn{3}{|c|}{ Low frequency ${ }^{a}$} & \multicolumn{3}{|c|}{ High frequency ${ }^{b}$} & \multirow{2}{*}{$\begin{array}{c}\text { Frequency } \\
\text { warning signc }\end{array}$} \\
\hline & Total & Boys & Girls & Total & Boys & Girls & \\
\hline 1-He criticizes the way I dress or make up & 80 & 78.9 & 80.5 & 20 & 21.1 & 19.5 & 58.7 \\
\hline 2- He asks me to change the way I dress or make up & 81.4 & 78.9 & 82.5 & 18.6 & 21.1 & 17.5 & 61.3 \\
\hline 3- He checks and controls my mobile or emails or social networks & 46.7 & 52.6 & 43.9 & 53.3 & 47.4 & 56.1 & 50 \\
\hline 4- He uses my passwords to supplant my identity or control me & 91.7 & 100 & 87.8 & 8.3 & 0 & 12.2 & 0 \\
\hline $\begin{array}{l}\text { 5- He tells me that he needs to know where I'm going, with who and what I'm } \\
\text { doing* }\end{array}$ & 45 & 78.9 & 29.3 & 55 & 21.1 & 70.7 & 65.2 \\
\hline $\begin{array}{l}\text { 6- He phones me several times to know where am I, with whom, what am } \\
\text { I doing and when are we going to see each other* }\end{array}$ & 47.5 & 78.9 & 32.5 & 52.5 & 21.1 & 67.5 & 56.3 \\
\hline 7- He frequently gets jealous & 10 & 21.1 & 4.9 & 90 & 78.9 & 95.1 & 66.6 \\
\hline 8- He accuses me of having an affair with another person with certain frequency & 68.3 & 73.7 & 65.9 & 31.7 & 26.3 & 34.1 & 48 \\
\hline 9- He often asks me not to go out with my friends & 75 & 94.7 & 65.9 & 25 & 5.3 & 34.1 & 18.2 \\
\hline 10- He speaks badly of my family or friends & 81.7 & 94.7 & 75.6 & 18.3 & 5.3 & 24.4 & 36.3 \\
\hline 11- He tries to isolate me from my friends and/ or family & 73.3 & 84.2 & 68.3 & 26.7 & 15.8 & 31.7 & 0 \\
\hline 12- He ignores me, he is only aware of his things & 67.8 & 73.7 & 65 & 32.2 & 26.3 & 35 & 53.8 \\
\hline
\end{tabular}


13- He ignores me or punishes me with silence

\begin{tabular}{cccccc|c}
59.3 & 57.9 & 60 & 40.7 & 42.1 & 40 & 54.5 \\
64.4 & 84.2 & 55 & 35.6 & 15.8 & 45 & 52.9 \\
72.9 & 94.7 & 62.5 & 27.1 & 5.3 & 37.5 & 42.9 \\
81.4 & 89.5 & 77.5 & 18.6 & 10.5 & 22.5 & 23.1 \\
64.4 & 84.2 & 55 & 35.6 & 15.8 & 45 & 41.2 \\
62.7 & 68.4 & 60 & 37.3 & 31.6 & 40 & 27.3 \\
93.1 & 89.5 & 94.9 & 6.9 & 10.5 & 5.1 & 0 \\
69.5 & 68.4 & 70 & 30.5 & 31.6 & 30 & 43.5 \\
85 & 94.7 & 80.5 & 15 & 5.3 & 19.5 & 25 \\
83.3 & 94.7 & 78 & 16.7 & 5.3 & 22 & 20 \\
30 & 36.8 & 26.8 & 70 & 63.2 & 73.2 & 74
\end{tabular}

14- He compares me with other girls and makes me feel uncomfortable and humiliated

15- He insults me or ridicules me publicly or privately

16- He frequently criticizes me publicly or privately for the way I think, speak or for other reasons

17- He tells me to shut up and not talk nonsense or makes fun of my opinions

18- He shouts and speaks badly at me

19- He threatens me, intimidates me or makes me feel afraid

20- He tells me he can't live without me, so I don't leave him, not even for a week to go on vacation, camping or on an excursion

21- He blackmails me saying that if I don't have sexual relationships with him, he will look for another girl

22- He pressures me to have sexual relationships when I don't want to

23- He is overprotective towards me, he considers he has to protect me and defend me

Note: In table only valid percentage of observed behaviours by adolescent population.

a Low frequency: percentage of behaviours that have "never" been observed and only "sometimes". b High frequency: percentage of behaviours observed "very often"; ' In table only valid percentage of the frequency with which adolescents consider that LIVBs have to occur to be warning signs.

Behaviours belonging to the control strategy were the most frequently observed among peers, ranging from $52.5 \%$ (item 6) to $90 \%$ (item 7) (Table 3). The unique sexist behaviour (item 23) was also highly observed (70\%). Some devaluation behaviours were also frequent in the adolescent environment although in lower rates than control strategy, ranging from $32.6 \%$ (item 12) to $40.6 \%$ (item 13). Girls observe 20 out of 23 WS more frequently than boys. A significant difference was found regarding 2 control WS: item 5 ( $p=$ $.000)$ and 6 which result is close to the significance level established in this study $(p=.001)$.

\section{Discussion}

Primary prevention is the most powerful resource for reducing rates of IPV against women (Heise, 2011). Among prevention guides, WS are under the spotlight for raising awareness among adolescents about the first signs of IPV.

Within the guides reviewed, WS are formulated differently. Some share similarities in content and severity, and others are mentioned in only one or few sources. However, there seems to be an implicit consensus on the relevance of including controlling and devaluating WS, since they are the only two strategies present in all eight sources. In addition, these behaviours are highly present in each one of the reviewed guides. Thus, we can assume that for the developers of the 8 sources, these behaviours have a greater importance among the rest. Threat \& intimidation, and sexual blackmail strategies are the next most represented, although they are not present in all sources, whereas emotional blackmail and sexist behaviours strategies are the less frequent. In a previous study performed with a large sample of adolescents (Díaz-Agüado et al., 2014), controlling and devaluating behaviours were the most prevalent ones, followed by threat \& intimidation, sexual blackmail behaviours and emotional blackmail. Thus, the representativeness of abusive behaviours seems to be in accordance with their prevalence in adolescent population.
Regarding the second objective, our aim was to know if adolescents identify abusive behaviours and not whether they perform them or not. Whereas in Luzón et al.'s study (2011) adolescents showed difficulties to identify abusive behaviours, our sample identified them all. Several hypotheses could be explaining this fact: (1) the capacity of adolescents to identify abusive behaviours is higher in a questionnaire than in the context of a real relationship; (2) in the last few years, the Spanish government has increased the number of awareness campaigns, setting the attention on controlling and devaluating behaviours (MSSI, 2014) and in general, social awareness about this problem has increased (Ferrer, \& Bosch, 2013), and; (3) the explanatory factors of why males perform abusive behaviours and females tolerate them, are others than their low capacity to identify them. In a two wave study performed with 16 to 21 year old Spanish women, results pointed out a similar prevalence in both periods, but a higher tolerance to different forms of abuse in the second period (Rodríguez-Franco et al., 2016). Thus, it could be possible that adolescents identify abusive behaviours but why they perform and tolerate them is another question.

The fact that abusive behaviours are already present in adolescent relationships has been clearly demonstrated even with a small sample. The frequency with which they observe them in their peer environment is considerably high comparing to the frequency with which adolescent population recognize having experienced IPV (Díaz-Aguado, et al., 2011; Díaz-Agüado, Martínez-Arias, \& Martín, 2014). It could be easier for them to identify abusive behaviours in other relationships or it could be an effect of the social desirability. Specific behaviours belonging to both control and devaluation strategies are the most observed, namely checking girlfriends' mobiles or networks, acting jealously, wanting to know where and with whom she is, comparing her contemptuously, and ignoring or undervaluing her. These same behaviours are considered by at least $40 \%$ of the sample, to have to occur very often to be IPV warning signs. The less ev- 
ident they are, the more frequently they have to appear to be WS. Similar results were found in a previous study with 289 Spanish adolescents that were especially tolerant with controlling and devaluating behaviours among others (Delgado \& Mergenthaler, 2011). Hence, adolescents present a high threshold tolerance towards the most observed abusive behaviours in their peer environment. In the Delphi study carried out a posteriori, experts labelled these same behaviours as LIVBs (Nardi-Rodríguez, et al., 2016). These are behaviours that are likely to appear at the beginning of a relationship. Such tolerance can push girls into the cycle of violence. Prevalence data can thus be related to adolescents' high tolerance to abusive behaviours, as the results of a recent study with a larger sample of young Mexican points out (Bringas-Molleda, et al., 2015). Arriaga, Capezza \& Daly (2016) found that tolerance threshold to aggressive behaviours increase when people are committed in a relationship. Further studies should focus on the explanatory factors of such tolerance.

Regarding the differences between sexes, although this study should be replicated with a larger sample, there seems to be a tendency among females to classify WS as more abusive and to observe them in higher rates than males.

In general, the outcomes of this study set the spotlight on controlling and devaluating behaviours for being prevalent in the adolescent environment and highly tolerated, which upholds the largest presence of both strategies in prevention programs and studies. Furthermore, in the Delphi study, experts (unaware of these results) classified the most observed and tolerated controlling and devaluating behaviours as LIVBs precursors to IPV and considered them relevant for primary prevention purposes (Nardi-Rodríguez, et al., 2016). Underline that controlling and devaluating strate-

\section{References}

Arriaga, X.B., Capezza, N.M., \& Daly, C.A. (2016). Personal Standards for Judging Aggression by a Relationship Partner: How Much Aggression Is Too Much? Journal of Personality and Social Psychology, 110, 36-54. doi: $10.1037 / \mathrm{pspi0000035}$

Bell, M.E., Cattaneo, L.B., Goodman, L.A., \& Dutton, M.A. (2008). Assessing the Risk of Future Psychological Abuse: Predicting the Accuracy of Battered Women's Predictions. Journal of Family Violence, 23, 69-80. doi: 10.1007/s10896-007-9128-5

Bonino, L. (1993). Varones y abuso doméstico, algunas ideas desde el campo de la salud mental y la perspectiva de género [Males and domestic abuse, some ideas from the field of mental health and gender], en A.E.N, Jornadas sobre salud mental y ley (celebradas en 1991), pp 193-218, Madrid: AEN.

Bringas-Molleda, C., Cortés-Ayala, L., Antuña-Bellerín, M. A., Flores-Galaz, M., López-Cepero, J. \& Rodríguez-Díaz, F. J. (2015). Análisis diferencial de la percepción de jóvenes sobre maltrato en el noviazgo. Revista Latinoamericana de Ciencias Sociales, Niñez y Juventud, 13(2), 737-748. doi: $10.11600 / 1692715 x .13213160315$

*Centro de Estudios de la Mujer (2011). ¿Y si yo... Test para frenar, detectar y prevenir la violencia de género [What if I?... Test for stopping, detecting and preventing gender violence]. Alicante: Centro de Estudios de la Mujer de la Universidad de Alicante. Retrieved from http://web.ua.es/es/cem/documentos/difusion-ysensibilizacion/actividades-curso-2011-12/25-de-noviembre/campanasemaforo.pdf gies have been identified as especially harmful for victims' mental and physical health, the most prevalent forms of psychological abuse, and strongly linked to physical violence (Bell et al., 2008).

The main limitation of this study is related to the sample size which implies that results cannot be generalized and must be considered with caution. In addition, the WS were pulled out from Spanish literature what may be an impediment for their use in other countries. Despite the high prevalence of controlling, devaluating and threat \& intimidation behaviours detected in UK, USA and Spanish guides (Picó, Pastor-Mira, Nardi-Rodríguez, \& López-Roig, 2013), deeper cross-cultural studies are necessary. Lastly, data do not reflect the prevalence of WS in relationships but the frequency with which they are observed. In contrast, we believe that the main strengths of this study rely on three points: (1) to date, prevention program developers, based on their own criteria include, the warning signs to work with adolescents. By contrast the results obtained offer a list with the most representative psychological WS in the Spanish literature for the development of future prevention programs. This list underpins an implicit consensus among developers on the relevance of including specific WS in prevention programs (2) controlling and devaluating behaviours in general, but as well specific ones, are essential in prevention programs, and (3) studies should focus on the explanatory factors of tolerating WS.

Acknowledgments.- The authors thank the Youth Center "Tucumán 7" in Alicante and all the adolescent boys and girls for participating in this study. The first author is supported by a predoctoral grant from "Consellería D’Educació, Cultura I Esport de la Generalitat Valenciana” (ACIF/2014/050)

Centre for Sociological Research, CIS (2013). Percepción Social de la Violencia de Género por la Adolescencia y la Juventud [Social Perception of Gender Violence among Adolescents and Youth]. Madrid: Delegación del Gobierno para la Violencia de Género. Retrieved from http://www.cis.es/cis/opencm/ES/1_encuestas/meses3.jsp

Delgado, C. \& Mergenthaler, E. (2011). Evaluación psicométrica de la percepción de la violencia de género en la adolescencia. International Journal of Developmental and Educational Psychology, 1(2), 197-206. Retrieved from

http://infad.eu/RevistaINFAD/2011/n1/volumen2/INFAD_010223 -197-206.pdf

*Díaz- Agüado, M., Martínez-Arias, R., Martín, J., Carvajal-Gómez, M., Peyró, M., \& Abril, V. (2011). Igualdad y prevención de la violencia de género en adolescentes. Madrid: Ministerio de Sanidad, Política Social e Igualdad.

*Díaz-Agüado, M., Martínez-Arias, R., \& Martín, J. (2014). La evolución de la adolescencia española sobre la igualdad y la prevención de la violencia de género [The evolution in Spanish adolescents on equality and prevention of gender violence]. Madrid: Ministerio de Sanidad, Servicios Sociales e Igualdad.

Ferrer, V. A. \& Bosch, E. (2013). Gender Violence as a Social Problem in Spain: Attitudes and Acceptability. Sex Roles, 70(11-12), 506-521. Retrieved from: https://www.researchgate.net/publication/268627721_Gender_Violen ce_as_a_Social_Problem_in_Spain_Attitudes_and_Acceptability?ev $=$ pr f_pub 
Fishbein, M. \& Ajzen, I. (2010). Predicting and Changing Behavior. The Reasoned Action Approach. New York: Psychology Press.

**Forest of Dean (s.f). Abuse in relationships. UK: Author. Retrieved from: http://www.fdean.gov.uk/nqcontent.cfm?a_id=6834

*Gálligo, F. (2010). Trátame bien...coeducación [Treat me right...Coeducation]. Sevilla: Instituto Andaluz de la Mujer. Retrieved from: http://www.juntadeandalucia.es/institutodelamujer/catalogo/doc/iam /2010/143309714.pdf

González- Ortega, I., Echeburúa, E., \& de Corral, P. (2008). Variables significativas en las relaciones violentas en parejas jóvenes: una revisión [Significant variables in violent relationships in young couples]. Behavioral Psychology, 16 (2), 207-225. Retrieved from http://www.funveca.org/revista/pedidos/product.php?id product $=31$ $\underline{9}$

Government's Delegation for Gender Violence(2015). Macroencuesta violencia contra la mijer 2015. Avance de resultados [Macro survey of violence against women. Preliminary results]. Madrid: Ministerio de Sanidad, Servicios Sociales e Igualdad. Retrieved from: http://www.msssi.gob.es/gabinetePrensa/notaPrensa/pdf/30.0330031 5160154508.pdf

Heise, L. (2011). What workes to prevent partner violence? An evidence overview. London: STRIVE Research Consortium. London School of Hygiene and Tropical Medicine (LSHTM). Retrieved December 19, 2012 from http://r4d.dfid.gov.uk/PDF/Outputs/Gender/60887. partnerViolenceEvidenceOverview.pdf

Henning, K., \& Kledges, L.M. (2003). Prevalence and characteristics of psychological abuse reported by court-involved battered women. Journal of Interpersonal Violence, 18, 857-871. doi: 10.1177/0886260503253878

*Instituto Andaluz de la Mujer (2009). Abre los ojos. El amor no es ciego [Open up your eyes. Love isn't blind]. Sevilla: Instituto Andaluz de la mujer. Retrieved from: http://www.juntadeandalucia.es/institutodelajuventud/sites/miraporlai gualdad/images/descargas/Abre $\% 201$ los $\% 20$ ojos.pdf

**Jewish Women International (n.d.). Dating Abuse. Washington: Author. Retrieved from http://www.jwi.org/page.aspx?pid=372

Kelly, V. (2004). Psychological abuse of women: A review of the literature. The Family Journal, 12(4), 383-388. doi 10.1111/j.17441617.2008.00215.x

Liles, S., Usita, P., Irvin, V. L., Hofstetter, C. R., Beeston, T., \& Hovell, M. F. (2012). Prevalence and correlates of intimate partner violence among young, middle, and older women of Korean descent in California. Journal of Family Violence, 27, 801-811. doi: 10.1007/s10896-012-9471-Z

**Love is Respect (2009). Power and Control Wheel. USA: Break the Cycle and the National Domestic Violence Hotline. Retrieved from http://www.loveisrespect.org/is-this-abuse/power-and-control-wheel

*Luzón, J.M., Ramos, E., Recio, P., \& de la Peña, E.M. (2011). Andalucía Detecta. Sexismo y Violencia de Género en la Juventud [Andalusia Detects. Sexism and Gender Violence in Youth]. Sevilla: Instituto Andaluz de la Mujer. Retrieved from: http://www.juntadeandalucia.es/institutodelamujer/index.php/coeduc acion/programa-para-prevenir-la-violencia-de-genero

Marshall, L. L. (1999). Effects of men's subtle and overt psycho-logical abuse on low-income women. Violence \& Victims, 14, 69-88.

Ministerio de Sanidad Servicios Sociales e Igualdad (2014). Cuéntalo. Hay salida a la violencia de género [Speak out. There is an issue to gender violence] [Social awareness Campaign]. Madrid: Author.
Nardi-Rodríguez, A., Pastor, M.A., López-Roig, S. y Ferrer-Pérez, V.A. (2016). Conductas violentas de baja intensidad: identificando objetivos eficaces para prevenir la violencia de género en adolescentes [Low intensity violent behaviours: selecting targets for preventing intimate partner violence against adolescent girls]. In V.A. Ferrer- Pérez. Violencia de género y su prevención en el ámbito educativo: posibilidades y alternativa. Symposium conducted at the meeting of VII Congreso Internacional de Psicología y Educación, Elche.

*Nuez del Rosario, L. (2005). Guía no sexista dirigida a chicas. No te líes con chicos malos [Non-sexist guide for girls. Do not get wound up with bad boys]. Madrid: Comisión para la Investigación de malos tratos a mujeres. Retrieved from http://malostratos.org/violencia-degenero/nuestras-publicaciones/

Picó, A., Pastor, M. A., Nardi-Rodríguez, A., \& López-Roig, S. (2013). Identificación y comparación de conductas violentas de baja intensidad a nivel transcultural IIdentification and comparison of low intensity violent behaviors from a cross-cultural perspective]. Unpublished manuscript, Universidad Miguel Hernández, Elche.

Pence, E., \& Paymar, M. (1993). Education groups for men who batter: The Duluth model. New York: Springer.

Povedano, A. (2014). Violencia de género en la adolescencia. Andalucía: IC editorial.

**Refuge. For women and children. Against domestic violence (2009). Starting in school. To end domestic violence. UK: Author. Retrieved from http://refuge.org.uk/ files/Starting-in-schools.pdf

*Rodríguez, V. (2010). Adolescentes y jóvenes de Castilla-La Mancha ante la violencia de género en las relaciones de pareja [Adolescents and youngsters of Castilla- La Mancha faced with gender violence in relationships]. Castilla-La Mancha: Instituto de la mujer de Castilla-La-Mancha. Retrieved from http://www.institutomujer.jccm.es/fileadmin/user_upload/WEB_201 1/CENTRO_DE_DOCUMENTACION/PUBLICACIONES/Adole scencia_y_Violencia.pdf

Rodríguez-Carballeira, Á., Porrúa-García, C., Escartín, J., Martín-Peña, J., \& Almendros, C. (2014). Taxonomy and hierarchy of psychological abuse strategies in intimate partner relationships. Anales de Psicología, 30(3), 916-926. doi: http://dx.doi.org/10.6018/analesps.30.3.154001

Rodríguez-Franco, L., López-Cepero, J., López-Nuñez, I., Paíno-Quesada S.G., Antuña-Bellerín, M.A., Bringas-Molleda, C., \& Rodríguez-Díaz, J. (2016). Evolution of victimization, tolerance and detection of intimate partner violence among young Spanish women. International Journal of Social Psychology, 3(1), 137-156. doi: 10.1080/02134748.2015.1101316

**The National Domestic Violence. Hotline. (2011). Warning Signs and Red Flags. Texas: Author. Retrieved from http://www.thehotline.org/isthis-abuse/abuse-defined/

**Think U Know (s.f). Under pressure? UK: Child Exploitation and Online Protection. Retrieved from https://www.thinkuknow.co.uk/14_plus/Need-advice/Relationshipabuse/

**This is abuse (s.f). Spot the signs. UK: Government Equality Office. Retrieved from http://thisisabuse.direct.gov.uk/worried-aboutabuse/view/spot-the-signs

(Article received: 20-04-2016; revised: 17-06-2016; accepted: 01-07-2016) 